MAŁGORZATA OLCZAK

Politechnika Łódzka

\title{
T3/ZOOM W EDUKACJI AKADEMICKIEJ (POSZUKIWANIE TEMATÓW PRAC DYPLOMOWYCH PRZEZ STUDENTÓW)
}

\begin{abstract}
Olczak Małgorzata, T3/ZOOM w edukacji akademickiej (poszukiwanie tematów prac dyplomowych przez studentów) [T3/ZOOM in Academic Education (Students' Search for The Diploma Theses' Topics)]. Studia Edukacyjne nr 42, 2016, Poznań 2016, pp. 333-355. Adam Mickiewicz University Press. ISSN 1233-6688. DOI: 10.14746/se.2016.42.20

Problem finding is described as behaviours, attitudes and cognitive processes that are responsible for creating a vision, posing and formulating problems. Problem finding is an alternative towards behaviours, attitudes and processes participating in solving problems (Jay, Perkins 1997). Problem finding constitutes a significant part of problem-based thinking related to the processes of discovering, formulating and reformulating problems (Szmidt 2003). It is active in "the first phase of solving problems when becoming curious about a situation we try to realise the difficulty and formulate a question that would adequately reflect the situation we find ourselves in as well as the goal we strive for" (Szmidt 2003, 23 [own transl.]). Hence, the question becomes the main element of the process of searching for the problem because it satisfies the cognitive anxiety, while the answer is the central element of the process of solving problems (Arlin 1990).

The author analyzed problem finding in the area of polytechnic education. She proposed employing her original T3/ZOOM technique of finding problems and cognitive tasks for the search for Bachelor's thesis topics by the students.
\end{abstract}

Key words: pedagogy of creativity, problem finding, diploma thesis

\section{Wprowadzenie}

Problem finding opisywany jest jako zachowania, postawy i procesy poznawcze kierujące tworzeniem wizji, stawianiem i formułowaniem problemów. Pozostaje on w opozycji wobec zachowań, postaw i procesów uczest- 
niczących w rozwiązywaniu problemów ${ }^{1}$, stanowiąc istotną część myślenia problemowego, związanego z procesami odkrywania, formułowania i reformułowania problemów ${ }^{2}$. Czynne

jest w pierwszej fazie rozwiązywania problemów, kiedy to zaciekawieni jakąś sytuacją próbujemy uświadomić sobie trudność i sformułować pytanie, które oddawało by dobrze sytuację, w której się znaleźliśmy i cel, do którego dążymy³.

Pytanie staje się więc głównym elementem procesu poszukiwania problemu, gdyż wieńczy niepokój poznawczy, gdy tymczasem odpowiedź jest centralnym elementem procesu rozwiązywania problemów ${ }^{4}$.

Problem finding autorka analizowała $\mathrm{w}$ obszarze edukacji politechnicznej. Zaproponowała zastosowanie autorskiej techniki dostrzegania problemów i zadań poznawczych T3/ZOOM do poszukiwania tematów prac licencjackich przez studentów.

\section{Problem finding}

Poznawcze koncepcje twórczości traktują ją jako proces twórczego rozwiązywania problemów (Creative Problem Solving - CPS). W modelach CPS punktem wyjścia czyni się model rozwiazywania problemów J. Deweya i badania E.P. Torrance`a.

J. Dewey ${ }^{5}$ wskazał pięć etapów twórczego rozwiązywania problemów: 1) odczucie trudności, 2) wykrycie jej i określenie, 3) nasuwanie się możliwego rozwiązania, 4) wyprowadzenie przez rozumowanie wniosków z przypuszczalnego rozwiązania, 5) dalsze obserwacje i eksperymenty prowadzące do przyjęcia lub odrzucenia przypuszczenia, czyli do wniosku zawierającego przeświadczenie pozytywne lub negatywne, zaś sam proces twórczy - na trzy zasadnicze fazy: uświadomienie sobie problemu oraz potrzeby jego rozwiązania, projektowanie hipotez (pomysłów rozwiązania problemu twórczego), rozwiązanie i weryfikacja założonych hipotez.

${ }^{1}$ E.S. Jay, D.N. Perkins, Problem finding: the Search for Mechanism, [w:] The Creativity Research Handbook, red. M.A. Runco, New Jersey 1997.

2 K.J. Szmidt, Szkoła przeciw myśleniu pytajnemu uczniów: próba określenia problemu, sugestie rozwiąania, Teraźniejszość - Człowiek - Edukacja, 2003, 2.

3 Tamże, s. 23.

4 P.K. Arlin, Wisdom: the art. Of problem finding, [w:] Wisdom: Its nature, origins and development, red. R.J. Sternberg, New York 1990.

${ }^{5}$ J. Dewey, Jak myślimy? Warszawa 1988. 
J.D. Bransford ${ }^{6}$ stworzył model usprawniający rozwiązywanie problemów. Opiera się on na badaniach prowadzonych przez M. Wertheimera7, G. Poly`a ${ }^{8}$, A. Newella i H.A. Simona9. Elementy składowe modelu przedstawia skrót, w którym:

I oznacza identyfikację problemów i możliwości,

D - definiowanie celów,

E - ekspozycję możliwych strategii działania,

A - antycypację wyników i podjęcie działań,

L - lustrację i wyciąganie wniosków.

J. Kozielecki ${ }^{10}$ wyszczególnia cztery etapy w twórczym rozwiązywaniu problemów:

- dostrzeganie problemu,

- analizę sytuacji problemowej,

- rozwiązywanie problemu: stawianie hipotez, wytwarzanie pomysłów,

- weryfikowanie hipotez, weryfikowanie pomysłów.

Etap dostrzegania problemu rozpoczyna się w chwili uświadomienia sobie jego pojawienia. $\mathrm{W}$ etapie analizy sytuacji problemowej analizowane są informacje zawarte $\mathrm{w}$ sytuacji problemowej, badane rozbieżności i luki między tym, co jest dane a tym, co jest pożądane. Po etapie wnikliwej analizy sytuacji problemowej rozpoczyna się zasadniczy akt rozwiązywania problemu, który powoduje konieczność stosowania całego systemu operacji intelektualnych, które mają doprowadzić do osiągnięcia postawionego celu, jakim jest pokonanie sformułowanej trudności (etap stawiania hipotez lub wytwarzania pomysłów). Mając pewne pomysły na rozwiązanie problemu, sprawdzane są te $\mathrm{z}$ nich, które wydają się słuszne - temu służy etap weryfikowania hipotez (weryfikowania pomysłów).

Przykładem CPS jest model procesu rozwiązywania problemów S.G. Isaksena, K.B. Dorvala, D.J. Treffingera11. Autorzy dzielą proces twórczego rozwiazywania problemów na trzy podstawowe fazy: zrozumienie problemu, gromadzenie pomysłów, planowanie działania. Każdą fazę budują nadto etapy szczegółowe, w których ważną rolę odgrywa zarówno myślenie dywergencyjne, jak i konwergencyjne.

6 J.D. Bransford, B.S. Stein, The Ideal Problem Solver, New York 1993.

${ }^{7}$ M. Wertheimer, Productive Thinking, New York 1945.

8 G. Polya, Jak to rozwiazać?, Warszawa 1993.

${ }^{9}$ A. Newell, H.A. Simon, Human Problem Solving, New York 1972.

10 J. Kozielecki, Twórczość i rozwiązywanie problemów, [w:] Psychologia i poznanie, red. M. Materska, T. Tyszka, Warszawa 1992.

11 S.G. Isaksen, K.B. Dorval, D.J. Treffinger, Creative approaches to problem solving, Dubuque 1994. 
I tak, faza rozumienia problemu przebiega przez etap 1: „Chaos”, w którym dzięki myśleniu dywergencyjnemu poszukiwane są możliwości rozwiązań, a dzięki myśleniu konwergencyjnemu określony zostaje cel ogólny rozwiązywania problemu. W etapie 2: „Analiza danych” myślenie dywergencyjne pozwala na spojrzenie na problem z różnych punktów widzenia, wynajdywanie szczegółów związanych z sytuacją problemową, zaś myślenie konwergencyjne - na ustalenie najważniejszych z posiadanych informacji. Etap 3: „Formułowanie problemu” pozwala na wykorzystanie myślenia dywergencyjnego do rozpatrzenia wielu możliwości sformułowanego problemu; dzięki myśleniu konwergencyjnemu dokonywany jest wybór konkretnego pytania problemowego.

W fazie gromadzenia pomysłów występuje etap 4: „Wytwarzanie pomysłów". Myślenie dywergencyjne pozwala na stworzenie wielu różnorodnych i nietypowych pomysłów, myślenie konwergencyjne - na identyfikację najbardziej obiecujących pomysłów.

Faza planowania działania przebiega przez etap 5: „Selekcję rozwiązan”, w którym myślenie dywergencyjne służy ustaleniu kryteriów analizy i sposobów ulepszenia obiecujących pomysłów, myślenie konwergencyjne odpowiada za wybór tych kryteriów i zastosowanie ich do selekcji rozwiązań. Etap 6: „Akceptacja rozwiązań" angażuje myślenie dywergencyjne do identyfikacji potencjalnych przeszkód i znalezienia sposobu ich pokonania; myślenie konwergencyjne odpowiada za sformułowanie szczegółowego planu działania.

Etapowość procesu twórczego oraz koncepcje postaciowe ze swym zasadniczym motywem przekonstruowywania wewnętrznej struktury dały impuls do poszukiwania nowego, głębszego i pełniejszego zrozumienia natury procesu twórczego. Zwolennicy tych poszukiwań łączyli proces twórczy z operacjami przetwarzania informacji, uznając wgląd" za centralny moment procesu twórczego i przyjmując jego określenie jako nagłą, nieoczekiwaną zmianę percepcji problemu ${ }^{12}$.

Współczesne koncepcje procesu twórczego odchodzą od schematu etapów, będącego zbyt sztywną i statyczną konstrukcją, bądź próbują przynajmniej uzupełnić go wiedzą dotyczącą konkretnych operacji intelektualnych, występujących w każdej fazie.

Podejście typu „nic specjalnego" charakteryzuje koncepcję D. Perkinsa i R.W. Weisberga ${ }^{13}$. D. Perkins uznał, że proces twórczy składa się z takich samych operacji umysłowych, jak każdy inny proces poznawczy. Różnicy

12 H.A. Simon, A. Newell, J. Dawidson, R. Sternberg, P. Langley, R. Jones, za: E. Nęcka, Proces twórczy i jego ograniczenia, Kraków 1999, s. 28.

${ }^{13}$ E. Nęcka, Twórczość, [w:] Psychologia, red. J. Strelau, Gdańsk 2000, s. 789. 
zaś upatrywał w specyfice celu procesu twórczego i jego wyniku. Cel polegał na wykryciu lub wytworzeniu nowej wiedzy lub na modyfikacji istniejących rozwiązań; wynik - na osiągnięciu rezultatów w postaci nowych i wartościowych idei. Specyfika celu i rezultatu procesu twórczego zależna jest natomiast od sposobu funkcjonowania pamięci, od sposobu zapamiętywania, a zwłaszcza odpamiętywania informacji.

Koncepcja R.W. Weisberga, zwana teorią "stopniowego przyrostu”, proces twórczy czyni normalnym i żmudnym; normalnym, bo pozbawionym specjalnych, specjalistycznych, czy specyficznych dla twórców zabiegów; żmudnym, bo charakteryzuje się systematyczną pracą, budowaniem dzieła „krok po kroku”. Proces twórczy nie musi zawierać przejść fazowych, jeśli osoba ma szansę odpowiednio długo analizować problem, kiedy otrzyma wskazówki naprowadzające ${ }^{14}$.

Dość liczną grupę modeli twórczości, określanych mianem „integracyjnych” lub „interakcyjnych"15, reprezentuje koncepcja interakcji twórczej E. Nęcki.

Koncepcja interakcji twórczej E. Nęcki16 powstała jako reakcja na fazowe traktowanie procesu twórczego, sztywność co do kolejności tych faz i ich nieprzenikalność. Dzielenie procesu twórczego na etapy - według autora nie jest wcale konieczne; podział taki może raczej prowadzić do fałszywych wniosków, nie oddawać prawdziwego charakteru procesu. Specyfika procesu twórczego polega bowiem na tym, iż ma on i elementy powrotu do wcześniejszych momentów, i elementy „wybiegające myślą naprzód”; na domiar tego - elementy te pojawiają się nieustannie $\mathrm{w}$ czasie całego procesu twórczego.

Element ciągłości procesu twórczego, powtarzalności pewnych jego fragmentów stanowi również osnowę modelu genploracji, zaproponowanego przez R.A. Finkego, T.B. Warda i S.M. Smitha ${ }^{17}$.

Odmienne spojrzenie na proces twórczy prezentuje M.A. Runco ${ }^{18}$. W swoim modelu twórczości, nazwanym przez autora The Two-Tiered Model of Creative Process (Dwuwarstwowy Model Procesu Twórczego), M.A. Runco uwzględnia zdolności i cechy poznawcze, które ujawniają się i rozwijają z jednej strony dzięki specjalnym zadaniom o charakterze dywergencyjnym,

14 Tamże, s. 790.

${ }_{15}$ M. Stasiakiewicz, Interakcyjne podejście do badania zachowań twórczych, [w:] Psychologiczne i psychometryczne problemy diagnostyki psychologicznej, red. J. Brzeziński, Poznań 1993.

16 E. Nęcka, Proces twórczy i jego ograniczenia, Kraków 1987.

17 E. Nęcka, Twórczość, s. 790-792.

${ }_{18}$ M.A. Runco, Creativity as optimal human functioning, [w:] Promoting creativity across the life span, red. M. Bloom, T.M. Gullotta, Washington 2001. 
z drugiej strony - pod wpływem sprzyjających twórczości warunków społecznych.

Jak widać z powyższego, różni autorzy wymieniają odmienną liczbę etapów (faz) procesu twórczego, wskazują odmienne ich zakresy oraz odmiennie je interpretują. Współczesna szkoła zakłada, że proces twórczego rozwiązywania problemów obejmuje sześć etapów, z tym że nie zawsze wszystkie muszą być realizowane19: (1) poszukiwanie celu, (2) ustalenie faktów, (3) znalezienie problemu, (4) ustalenie koncepcji, (5) znalezienie rozwiązania, (6) znalezienie akceptacji. W skład każdego etapu wchodzą zarówno czynności myślenia zbieżnego (konwergencyjnego), jak i rozbieżnego (dywergencyjnego). Myślenie rozbieżne rozwija i poszerza proces myślenia. Myślenie tego typu rozpoczyna się od określonego problemu lub koncepcji i tworzy różne punkty widzenia. Chodzi o pozbycie się wszelkich ograniczeń i rozważenie wszelkich możliwości. Myślenie zbieżne jako naturalne przedłużenie myślenia rozbieżnego stosowane jest $\mathrm{w}$ celu ograniczenia dostępnych opcji i uzyskania wielu zadowalających rozwiązań danego problemu lub decyzji. Myślenie w sposób zbieżny rozpoczyna się od szerokiego spojrzenia na problem, po czym koncentruje na poszczególnych zagadnieniach lub opcjach.

Mimo widocznych różnic w koncepcjach etapów twórczego rozwiązywania problemów, daje się wyodrębnić dwie podstawowe fazy tego procesu, a mianowicie: pierwszą - nastawioną na wytwarzanie czegoś nowego, i drugą - polegającą na weryfikacji, czyli wyborze i ocenie, pomysłów rozwiązania. Wydzielenie dwóch faz procesu twórczego rozwiązywania problemów jest nader trafne - zbiega się bowiem z ideą etapów czynności myślenia:

Wytwarzanie i weryfikacja to dwa względnie odrębne procesy myślowe (...). Pierwszy z nich jest systemem wytwarzającym różnorodne pomysły rozwiązania, drugim zaś - systemem weryfikującym te pomysły $(\ldots)^{20}$.

Bliższa analiza klasycznych już dziś koncepcji etapów procesu twórczego pozwala dostrzec i ten wspólny (a ważny z punktu widzenia tej wypowiedzi) motyw, iż zaczyn procesu twórczego rozwiązywania problemów tkwi w odkryciu problemu. Wyjątkową uwagą otoczony jest proces dostrzegania problemu $\mathrm{w}$ nurcie poznawczym. Dostrzeganie problemu jawi się więc jako proces dobierania danych, jako proces ich porównywania, łączenia

19 T. Proctor, Twórcze zarządzanie, Warszawa 1998.

20 J. Kozielecki, Zagadnienia psychologii myślenia, Warszawa 1968, s. 24-25. 
na zasadzie analogii. Sytuacja posiadania wiedzy w obrębie danej dziedziny ujawnia jej problem.

Czynności przygotowawcze, takie jak dostrzeganie i określanie problemu, mają charakter priorytetowy dla M. Csikszenmihalyi, decydują bowiem o jakości twórczości, innowacji, czy działania wynalazczego. To, w jakim obszarze problem jest zauważony, jaki zakres tego obszaru problem podejmuje, ilość i jakość wiedzy zgromadzonej na temat danego problemu stanowi zasadniczo o stopniu oryginalności samego rozwiązania, a także jego efektywnym funkcjonowaniu wśród innych zdobyczy techniczno-naukowych. Niemal tożsame stanowisko reprezentuje J.W. Getzels ${ }^{21}$. Według autora, twórczy ludzie aktywnie angażują się $\mathrm{w}$ procesy identyfikowania problemów, ich zachowania eksploracyjne wiodą wprost do problemów oczekujących rozwiązania, wysoce subiektywne oceny przestrzeni problemów pozwalają im na odkrycia online.

Przykładem podobnej wizji i znaczenia etapu dostrzegania problemu jest koncepcja inwestycyjna. Dostrzeżenie problemu na polu „zaniedbanym”, „zapomnianym”, „nie urabianym” przez twórców - „na ugorze” - jest, mówiąc żargonem giełdowym, dobrą inwestycją. Rozwiązanie podjętego z obszarów zaniedbanych problemu ma szansę stać się wysoko cenionym, odkrywczym i zaskakująco potrzebnym.

$\mathrm{W}$ modelu genploracji etap dostrzegania problemu stoi na drugim miejscu. Nie znaczy to, iż jest mniej ważny. Znaczy tylko tyle, że w strukturze procesu twórczego dostrzeganie problemu poprzedzone jest tworzeniem tzw. struktury przedtwórczej. Strukturę przedtwórczą, będącą „produktem” nowym, choć nie do końca określonym, a więc dwuznacznym, „wprowadza się" kolejno w różne konteksty, w różne obszary i tym sposobem szuka dla niej eksploatacji22. Dostrzeganie problemu sprowadzone zostało więc do czynności szukania zastosowania dla struktury przedtwórczej.

\section{T3/ZOOM - prezentacja techniki dostrzegania problemów i zadań poznawczych}

T3/ZOOM jest techniką dostrzegania problemów i zadań poznawczych. Należy do procesu twórczego rozwiązywania problemów.

${ }^{21}$ J.W. Getzels, M. Csikszenmihalyi, The creative vision: A longitudinal study of problem finding in art, New York 1976.

${ }_{22}$ M. Olczak, Trening twórczości - wspótczesna i efektywna forma wychowania przez sztukę, Kraków 2009. 
Wzorem procesu twórczego rozwiązywania problemów jest system TRoP, który zaproponowała E. Nęcka ${ }^{23}$. Składa się on z trzech etapów $\mathrm{w}$ fazie pierwszej, polegającej na opracowaniu samego problemu, a następnie $-\mathrm{z}$ trzech etapów $\mathrm{w}$ fazie drugiej, polegającej na wytwarzaniu rozwiązań problemu. Etapy i zabiegi fazy pierwszej nazwane zostały przez autora „przestrzenią problemu”, zaś etapy i zabiegi fazy drugiej - „przestrzenią rozwiązań". Podział na tzw. przestrzeń problemu i przestrzeń rozwiązań jest zgodny z podejściem fazowym w psychologii myślenia. Toteż, idea dzielenia procesu rozwiązywania problemów na kolejne fazy nie jest odkrywcza, bowiem jest oczywiste, z czym autor systemu się zgadza, iż chcąc rozwiązać problem, trzeba go najpierw wykryć, potem sformułować, wytworzyć pomysły rozwiązań, a dalej je zweryfikować i ewentualnie wdrożyć.

T3/ZOOM ma służyć wykrywaniu problemów i zadań poznawczych, czyli należy do pierwszej fazy systemu TRoP („przestrzeni problemu"), w której dochodzi do identyfikowania i formułowania problemu. T3/ZOOM polega na doszukiwaniu się problemów i zadań poznawczych sytuacji wyjściowej:

- w dwóch przeciwstawnych kierunkach widzenia tejże sytuacji. Kierunek polegający na uszczegółowianiu, wyszczególnieniu pojedynczego elementu danej sytuacji wyznaczony jest przez „szkło powiększające”. Kierunek ujmujący sytuację $\mathrm{w}$ szerokiej perspektywie, by nie rzec globalnie, wyznacza "obiektyw szerokokątny";

- w trzech wglądach, w każdym z kierunków. Wglądy "stopniują" doszukiwanie się problemów i zadań poznawczych. Mamy więc pierwsze spojrzenie na sytuację: „to, co widać na pierwszy rzut oka”, mamy i drugą odsłonę sytuacji: "to, co mniej widoczne”, a także trzeci wgląd w sytuację: "to, czego nie widać, a na pewno jest".

Dzięki zarówno obu kierunkom penetracji sytuacji, jak i trzem wglądom możemy odnaleźć osobiście sześć problemów danej sytuacji lub wielokrotność tej liczby, zwłaszcza gdy pracuje się zespołowo.

Obraz graficzny techniki T3/ZOOM prezentuje się następująco:

\begin{tabular}{|c|c|c|c|}
\hline & $\begin{array}{l}\text { A. "to, co widać } \\
\text { na pierwszy rzut } \\
\text { oka” }\end{array}$ & $\begin{array}{l}\text { B. "to, co mniej } \\
\text { widoczne” }\end{array}$ & $\begin{array}{l}\text { C. „to, czego nie } \\
\text { widać, a na pewno } \\
\text { jest" }\end{array}$ \\
\hline 1. „szkło powiększające" & $1 \mathrm{~A}$ & $1 \mathrm{~B}$ & $1 \mathrm{C}$ \\
\hline 2. „obiektyw szerokokątny” & $2 \mathrm{~A}$ & $2 \mathrm{~B}$ & $2 \mathrm{C}$ \\
\hline
\end{tabular}

${ }^{23}$ E. Nęcka, TRoP. Twórcze rozwiązywanie problemów, Kraków 1994. 
Prezentując T3/ZZOM należy przede wszystkim wskazać jej zastosowanie, przebieg oraz wykorzystanie.

\section{T3/ZOOM}

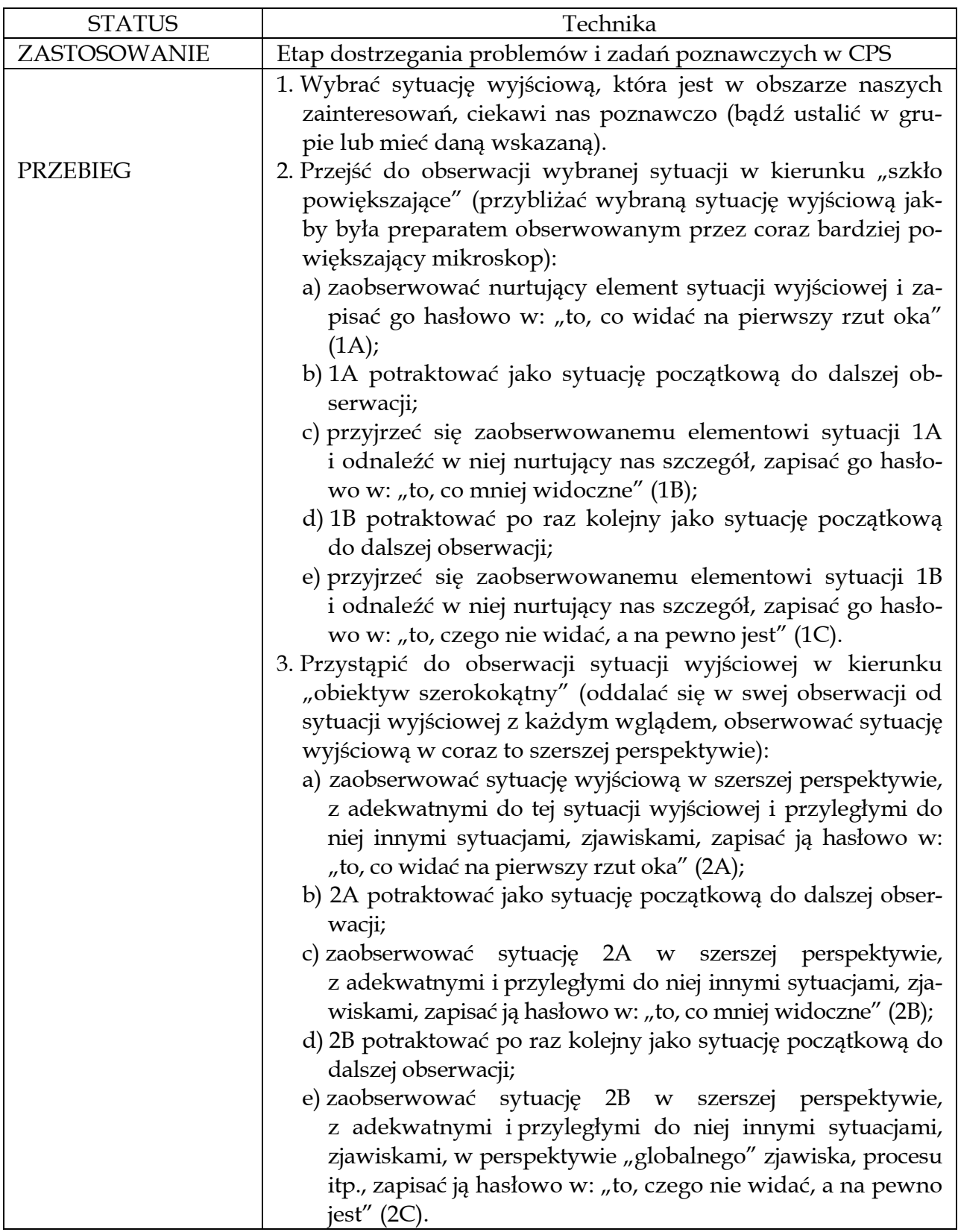




\begin{tabular}{|c|c|}
\hline STATUS & Technika \\
\hline & $\begin{array}{l}\text { 4. Przyjrzeć się wszystkim zapisanym sytuacjom (1A, 1B, 1C, } \\
\text { 2A, 2B, 2C), wybrać najbardziej interesującą, będącą od tej } \\
\text { chwili problemem (zadaniem poznawczym) gotową do } \\
\text { wprowadzenia do CPS. }\end{array}$ \\
\hline REGUŁY & $\begin{array}{l}\text { - Zapisywać propozycje dostrzeganych problemów (zadań } \\
\text { poznawczych) hasłowo. } \\
\text { - Nie przerywać raz rozpoczętej obserwacji i toku myślowego. } \\
\text { - Podczas doszukiwania się szczegółów sytuacji w kierunku } \\
\text { „szkło powiększające” starać się zachować między wglądami } \\
\text { równe odstępy przybliżania. } \\
\text { - Podczas oddalania się od sytuacji wyjściowej, obserwowania } \\
\text { jej w perspektywie szerszych zjawisk, procesów w kierunku } \\
\text { "obiektyw szerokokątny” starać się zachować między wglą- } \\
\text { dami równe odstępy oddalania. } \\
\text { Podczas pracy grupowej: } \\
\text { - unikać krytyki, nie oceniać proponowanych pomysłów pro- } \\
\text { blemów (zadań poznawczych), } \\
\text { - dyskutować i wybierać do zapisu tylko te problemy (zadania } \\
\text { poznawcze), które grupie wydały się wyjątkowo ciekawe po- } \\
\text { znawczo bądź na które zwrócili uwagę wszyscy członkowie } \\
\text { grupy - dali bowiem tym sposobem dowód ważkości, po- } \\
\text { wszechności danego problemu (zadania poznawczego), } \\
\text { - wybrać osobę zapisującą, } \\
\text { - ustalać wspólnie zapis hasłowy pomysłów problemów (zadań } \\
\text { poznawczych), } \\
\text { - udostępnić każdorazowo wszystkim członkom grupy pracę } \\
\text { do odczytu. }\end{array}$ \\
\hline ORGANIZACJA & $\begin{array}{l}\text { 1. Zaprosić uczestników do sali, w której będą pracować. } \\
\text { 2. Przedstawić uczestnikom technikę i obowiązujące reguły. } \\
\text { 3. Utworzyć grupy 5-6-osobowe, gdy przewidujemy prace ze- } \\
\text { społową. } \\
\text { 4. Przygotować środki pomocnicze. } \\
\text { 5. Przewidzieć czas na prezentację pomysłów problemów (za- } \\
\text { dań poznawczych). }\end{array}$ \\
\hline ŚRODKI & $\begin{array}{l}\text { - Pomieszczenie i stanowisko do pracy indywidualnej lub ze- } \\
\text { społowej. } \\
\text { - Kartki z rozrysowanym szablonem techniki lub tablica, na } \\
\text { której rozrysowano schemat techniki, kartki, narzędzia pisar- } \\
\text { skie. }\end{array}$ \\
\hline WYKORZYSTANIE & $\begin{array}{l}\text { Poszukiwanie pomysłów problemów/zadań poznawczych dla } \\
\text { wybranej, danej lub ustalonej w grupie sytuacji wyjściowej, by } \\
\text { dalej sformułować problem/zadanie poznawcze w postaci py- } \\
\text { tania heurystycznego, a w konsekwencji go rozwiązać. } \\
\text { Poszukiwanie pomysłów problemów/zadań poznawczych } \\
\text { z kręgu zadań pragmatycznych. }\end{array}$ \\
\hline
\end{tabular}




\section{Zastosowanie T3/ZOOM do poszukiwania tematu pracy dyplomowej - eksperyment}

Eksperyment ${ }^{24}$ objął zbiorowość kształcących się dorosłych. Badanymi byli studenci studiów stacjonarnych i niestacjonarnych Politechniki Łódzkiej. Przyjęto $w$ perspektywie licznych raportów, iż istnieje konieczność kształcenia ludzi kreatywnych, mobilnych do wszelkich przyszłych, jeszcze bliżej nieokreślonych zmian gospodarczo-ekonomicznych. Należy więc przyjąć, iż badani to ogół dorosłych kształcących się i sposobiących do pełnego wykorzystania potencjału twórczego w środowisku zawodowym ${ }^{25}$.

W eksperymencie posłużono się techniką T3/ZOOM do poszukiwania zadania, będącego nicią przewodnią - tematem pracy dyplomowej studentów. Poszukiwanie zadania za pośrednictwem T3/ZOOM odbywało się w sytuacji niedostateczności sposobów i pozwalało zadośćuczynić potrzebie osiągania wartości (nowe i cenne dla jednostki zadanie kontynuowane w pracy licencjackiej). Odszukane zadanie poznawcze było wartościowane indywidualnie (zadanie nowe i cenne dla jednostki) oraz przez promotora pracy dyplomowej (zadanie poznawcze dopuszczone do rozwinięcia $\mathrm{w}$ pracy licencjackiej) i przez jurorów (oceniających stopień wykorzystania zadania poznawczego w pracy dyplomowej na podstawie określonych wskaźników jakościowych).

Względem eksperymentu przeprowadzono badania ilościowe i jakościowe ${ }^{26}$. W badaniu posłużono się m.in. miniwywiadem. Zastosowano go $\mathrm{w}$ stosunku do promotorów prac dyplomowych. Zawierał pytanie: czy wskazana przez studenta tematyka pracy licencjackiej zbieżna jest z dostrzeżonym zadaniem poznawczym, odszukanym z użyciem T3/ZOOM? Promotorzy odpowiadając na pytanie wywiadu, mogli wskazać jedną z trzech odpowiedzi:

- odszukane przez studenta zadanie poznawcze realizowane jest $\mathrm{w}$ pracy licencjackiej $w$ petni;

- wskazane zadanie poznawcze znajduje realizację w pracy dyplomowej pośrednio, częściowo;

${ }^{24}$ M. Olczak, Jakość dostrzegania problemów i zadań poznawczych - istotny czynnik wychowania do twórczości. T3/ZOOM technika wspomagania rozwoju myślenia twórczego uczacych się, Łódź 2013.

${ }^{25}$ G.R. Oldham, A. Cummings, Employee Creativity: Personal and Contextual Factors at Work, The Academy of Management Journal, 1996, 39, 3, p. 607-634; R. Florida, The Rise of the Creative Class and How It's Transforming Work. Leisure, Community and Everyday Life, New York 2002.

${ }^{26}$ M. Olczak, Jakość dostrzegania problemów i zadań poznawczych. 
- nie, tematyka pracy licencjackiej nie pokrywa się z zadaniem poznawczym uchwyconym i wskazanym przez studenta.

W badaniu użyto ponadto analizy według wskaźników jakościowych, opracowanych na podstawie poziomów twórczości technicznej G.S. Altszullera $^{27}$ :

- zadanie poznawcze, odszukane techniką T3/ZOOM, jest jedynie impulsem dla pracy licencjackiej - praca licencjacka przebiega dalej niezależnie od wytypowanego do rozwinięcia w pracy zadania poznawczego - I stopień (wykorzystania zadania poznawczego w pracy licencjackiej);

- zadanie poznawcze jest detalem pracy licencjackiej - II stopień (wykorzystania zadania poznawczego w pracy licencjackiej);

- zadanie poznawcze zostało połączone $\mathrm{z}$ innym zadaniem, zagadnieniem, stanowiąc istotny fragment pracy licencjackiej - III stopień (wykorzystania zadania poznawczego w pracy licencjackiej);

- praca licencjacka jest rozprawą wokół zadania poznawczego, odszukanego za pośrednictwem T3/ZOOM - IV stopień (wykorzystania zadania poznawczego w pracy licencjackiej).

Niezależni jurorzy oceniali: $\mathrm{w}$ jakim stopniu zadanie poznawcze dostrzeżone dzięki użyciu techniki T3/ZOOM zostało urzeczywistnione w pracy dyplomowej?

\section{Wybrane realizacje dyplomowe}

PRZYKŁAD 1

Zadanie poznawcze rozwinięte w pracy dyplomowej:

- odpowiedź badanego na pytanie: czy któreś z zadań poznawczych nowych i cennych, odszukanych za pośrednictwem T3/ZOOM, znalazło swoje rozwinięcie $\mathrm{w}$ pracy licencjackiej - tak;

- opinia promotora: odszukane przez studenta zadanie poznawcze zrealizowane jest w pracy licencjackiej - w petni;

- ocena jurorów: praca licencjacka jest rozprawą wokół zadania poznawczego, odszukanego za pośrednictwem T3/ZOOM - IV stopień (wykorzystania zadania poznawczego $\mathrm{w}$ pracy licencjackiej). 
Hasło wyjściowe: komunikacja społeczna

\begin{tabular}{|c|c|c|c|}
\hline & $\begin{array}{l}\text { to, co widać } \\
\text { na pierwszy rzut } \\
\text { oka }\end{array}$ & $\begin{array}{l}\text { to, co mniej wi- } \\
\text { doczne }\end{array}$ & $\begin{array}{l}\text { to, czego nie widać, } \\
\text { a na pewno jest }\end{array}$ \\
\hline $\begin{array}{l}\text { "szkło } \\
\text { powiększające" }\end{array}$ & $\begin{array}{l}\text { porozumiewanie } \\
\text { się }\end{array}$ & $\begin{array}{l}\text { specyfika porozu- } \\
\text { miewania sie } \\
\text { w miejscu pracy }\end{array}$ & $\begin{array}{l}\text { trudności jednostki } \\
\text { w porozumiewaniu } \\
\text { się ze względu na } \\
\text { sytuacje w miejscu } \\
\text { pracy }\end{array}$ \\
\hline \multirow{2}{*}{$\begin{array}{l}\text { "obiektyw } \\
\text { szerokokątny" }\end{array}$} & \multirow{2}{*}{$\begin{array}{l}\text { zestaw znaków } \\
\text { i symboli dostęp- } \\
\text { nych ludziom do } \\
\text { porozumiewania } \\
\text { się }\end{array}$} & $\begin{array}{l}\text { specyfika zestawu } \\
\text { znaków i symboli } \\
\text { w zależności od } \\
\text { społeczności }\end{array}$ & $\begin{array}{l}\text { zróżnicowanie kul- } \\
\text { turowe znaków } \\
\text { i symboli służących } \\
\text { porozumiewaniu się }\end{array}$ \\
\hline & & warianty językowe & $\begin{array}{l}\text { trudności w ich } \\
\text { interpretacji na } \\
\text { poziomie kulturo- } \\
\text { wym }\end{array}$ \\
\hline
\end{tabular}

Anna K.

Temat pracy: Komunikacja interpersonalna w organizacji

Fragment spisu treści:

\section{Proces komunikacji}

I.1. Pojęcie komunikacji

I.2. Znaczenie i cele komunikacji

I.3. Schemat i modele procesu komunikacji

I.4. Zasady skutecznej komunikacji

I.5. Rodzaje komunikacji

I.6. Typy komunikowania się

I.7. Formy komunikowania się

I.8. Style komunikowania się

I.9. Bariery i zakłócenia procesu komunikacyjnego

Podsumowanie

\section{Specyfika komunikacji interpersonalnej w organizacji}

II.1. Znaczenie i cele komunikacji w organizacji

II.2. Style komunikowania się w organizacji

II.3. Formy komunikowania się w organizacji

II.4. Kierunki sieci przepływu informacji

II.5. Wymogi i zasady sprawnego komunikowania się w organizacji 
II.6. Błędy w komunikowaniu się w organizacji

II.7. Sposoby przezwyciężania problemów komunikacyjnych - wybrane metody racjonalizacji systemów komunikowania się

II.7.1. KSS - metoda analizy i projektowania systemu komunikacji

II.7.2. KIWA - analiza wartości informacji i komunikowania się

II.8. Grupowe komunikowanie się w organizacji

II.9. Techniczne instrumenty wspomagania procesów komunikacyjnych w organizacji

Podsumowanie

Badania własne: polegały na zdiagnozowaniu wiedzy na temat procesu komunikacyjnego i umiejętności skutecznego komunikowania się w firmie $X$. Do badań posłużyła ankieta i test wiadomości.

\section{PRZYKŁAD 2}

Zadanie poznawcze rozwinięte w pracy dyplomowej:

- odpowiedź badanego na pytanie: czy któreś z zadań poznawczych nowych i cennych, odszukanych za pośrednictwem T3/ZOOM znalazło swoje rozwinięcie $\mathrm{w}$ pracy licencjackiej - tak;

- opinia promotora: wskazane zadanie poznawcze znajduje realizacje w pracy dyplomowej pośrednio - tak, ale częściowo;

- ocena jurorów: zadanie poznawcze jest detalem pracy licencjackiej II stopień (wykorzystania zadania poznawczego w pracy licencjackiej.

Hasto wyjściowe: praca

\begin{tabular}{|c|c|c|c|}
\hline & $\begin{array}{l}\text { to, co widać } \\
\text { na pierwszy rzut } \\
\text { oka }\end{array}$ & $\begin{array}{l}\text { to, co mniej } \\
\text { widoczne }\end{array}$ & $\begin{array}{l}\text { to, czego nie widać, } \\
\text { a na pewno jest }\end{array}$ \\
\hline $\begin{array}{l}\text { „szkło powiększa- } \\
\text { jące” }\end{array}$ & zawód & $\begin{array}{l}\text { ranking zawodów } \\
\text { (zawody o wyso- } \\
\text { kim i niskim statu- } \\
\text { sie społecznym) } \\
\end{array}$ & $\begin{array}{l}\text { uwarunkowania } \\
\text { wyboru zawodu } \\
\text { (zwt. tego o niskim } \\
\text { statusie społecznym) }\end{array}$ \\
\hline \multirow{3}{*}{$\begin{array}{l}\text { "obiektyw szero- } \\
\text { kokątny" }\end{array}$} & \multirow{3}{*}{$\begin{array}{l}\text { wysiłek, } \\
\text { trud, } \\
\text { obowiązek }\end{array}$} & \multirow{3}{*}{$\begin{array}{l}\text { wykształcenie, } \\
\text { kwalifikacje, } \\
\text { kompetencje, } \\
\text { umiejętności }\end{array}$} & samorealizacja \\
\hline & & & $\begin{array}{l}\text { indywidualna } \\
\text { ścieżka kariery }\end{array}$ \\
\hline & & & „Wyścig szczurów” \\
\hline
\end{tabular}


Marta K.

Temat pracy: Zawody o niskim prestiżu społecznym na przykładzie firmy $X$

Fragment spisu treści:

\section{Praca i jej uwarunkowania}

I.1. Praca jako wartość i obszar samorealizacji

I.2. Zakresy pojęć: wykształcenie, zawód, praca

I.3. Wybór zawodu a samoocena i predyspozycje do jego wykonywania

I.4. Zakład pracy - charakterystyka i funkcje

I.5. Zawody o niskim prestiżu społecznym - uwarunkowania opinii społecznej i wyboru przez ludzi takich zawodów

Podsumowanie

Badania własne: polegały na wyłonieniu czynników mających znaczenie dla wyboru zawodu o niskim statusie społecznym na przykładzie pracowników z firmy $X$. Do badań posłużyły: kwestionariusz wywiadu, kwestionariusz osobowy oraz załączone wnioski, np. o udzielenie pomocy z ZFRON, ZFSŚ.

\section{PRZYKŁAD 3}

Zadanie poznawcze rozwinięte w pracy dyplomowej:

- odpowiedź badanego na pytanie: czy któreś z zadań poznawczych nowych i cennych, odszukanych za pośrednictwem T3/ZOOM znalazło swoje rozwinięcie w pracy licencjackiej - tak;

- opinia promotora: wskazane zadanie poznawcze znajduje realizację w pracy dyplomowej pośrednio - tak, ale częściowo;

- ocena jurorów: zadanie poznawcze jest detalem pracy licencjackiej II stopień (wykorzystania zadania poznawczego w pracy licencjackiej.

Hasło wyjściowe: menedżer

\begin{tabular}{|l|l|l|l|}
\cline { 2 - 4 } \multicolumn{1}{c|}{} & $\begin{array}{l}\text { to, co widać } \\
\text { na pierwszy rzut oka }\end{array}$ & $\begin{array}{l}\text { to, co mniej wi- } \\
\text { doczne }\end{array}$ & $\begin{array}{l}\text { to, czego nie widać, } \\
\text { a na pewno jest }\end{array}$ \\
\hline $\begin{array}{l}\text { "szkło } \\
\text { powiększające" }\end{array}$ & profesja & $\begin{array}{l}\text { zasób koniecznych } \\
\text { umiejętności }\end{array}$ & $\begin{array}{l}\text { faktycznie posiada- } \\
\text { ne umiejętności }\end{array}$ \\
\hline
\end{tabular}




\begin{tabular}{|c|c|c|c|}
\hline & role w pracy mene- & $\begin{array}{l}\text { wywieranie wpły- } \\
\text { wu na zespół pra- } \\
\text { cowników }\end{array}$ & $\begin{array}{l}\text { budowanie organi- } \\
\text { zacji }\end{array}$ \\
\hline $\begin{array}{l}\text { "obiektyw } \\
\text { szerokokątny" }\end{array}$ & $\begin{array}{l}\text { dżerskiej, } \\
\text { m.in. reprezentanta, } \\
\text { tacznika, rzecznika, } \\
\text { przywódcy, coacha }\end{array}$ & $\begin{array}{l}\text { metody i techniki } \\
\text { oddziaływania na } \\
\text { pracowników ze } \\
\text { względu na kre- } \\
\text { owane przez mene- } \\
\text { dżera role }\end{array}$ & styl organizacji \\
\hline
\end{tabular}

Adriana J.

Temat pracy: Rola menedżera jako coacha $\mathrm{w}$ rozwoju zawodowym pracowników

Fragment spisu treści:

\section{I. Środowisko pracy}

I.1. Praca i środowisko pracy

I.2. Rozwój zawodowy

I.3. Menedżer - kierowanie ludźmi w organizacji

Podsumowanie

\section{Coaching}

II.1. Profesjonalizacja coachingu

II.2. Umiejętności coacha

II.3. Zasady prowadzenia coachingu

II.4. Zadania coachingu

II.5. Funkcje coachingu w organizacji

Podsumowanie

Badania własne: polegały na ocenie efektywności pracy menedżera występującego $\mathrm{w}$ roli coacha we wspieraniu rozwoju zawodowego pracowników firmy $X$. Badania miały charakter porównawczy - wywiady przeprowadzono wśród pracowników i menedżerów.

\section{PRZYKEAD 4}

Zadanie poznawcze rozwinięte w pracy dyplomowej:

- odpowiedź badanego na pytanie: czy któreś z zadań poznawczych nowych i cennych, odszukanych za pośrednictwem T3/ZOOM znalazło swoje rozwinięcie w pracy licencjackiej - tak; 
- opinia promotora: odszukane przez studenta zadanie poznawcze zrealizowane jest w pracy licencjackiej - w petni;

- ocena jurorów: praca licencjacka jest rozprawą wokół zadania poznawczego, odszukanego za pośrednictwem T3/ZOOM - IV stopień (wykorzystania zadania poznawczego $\mathrm{w}$ pracy licencjackiej.

Hasło wyjściowe: pracownik

\begin{tabular}{|c|c|c|c|}
\hline & $\begin{array}{l}\text { to, co widać } \\
\text { na pierwszy rzut oka }\end{array}$ & $\begin{array}{l}\text { to, co mniej wi- } \\
\text { doczne }\end{array}$ & $\begin{array}{l}\text { to, czego nie wi- } \\
\text { dać, } \\
\text { a na pewno jest }\end{array}$ \\
\hline $\begin{array}{l}\text { „szkło } \\
\text { powiększające" }\end{array}$ & $\begin{array}{l}\text { zadania i obowiązki } \\
\text { związane } \\
\text { ze stanowiskiem }\end{array}$ & $\begin{array}{l}\text { atmosfera } \\
\text { w środowisku } \\
\text { pracy }\end{array}$ & $\begin{array}{l}\text { odczucia związa- } \\
\text { ne } \\
\text { z pracą, np. po- } \\
\text { ziom satysfakcji } \\
\text { z pracy }\end{array}$ \\
\hline \multirow{2}{*}{$\begin{array}{l}\text { "obiektyw } \\
\text { szerokokątny" }\end{array}$} & $\begin{array}{l}\text { stanowisko } \mathrm{w} \text { hierarchii } \\
\text { organizacji }\end{array}$ & $\begin{array}{l}\text { doskonalenie sie } \\
\text { w zawodzie }\end{array}$ & \multirow{2}{*}{ drabina kariery } \\
\hline & $\begin{array}{l}\text { dobór jednostki do } \\
\text { stanowiska pracy }\end{array}$ & $\begin{array}{l}\text { system naboru } \\
\text { w organizacji }\end{array}$ & \\
\hline
\end{tabular}

Kamila J.

Temat pracy: Doskonalenie zawodowe pracowników firmy $X$

Fragment spisu treści:

\section{Doskonalenie zawodowe pracowników}

I.1. Doskonalenie zawodowe, dokształcanie - próba zdefiniowania pojęć

I.2. Szkolenia mające wpływ na rozwój zawodowy pracownika

I.3. Szkolenia mające wpływ na rozwój osobowości

I.4. Programy rozwojowe

Podsumowanie

Badania własne: polegały na zdiagnozowaniu rozwoju zawodowego pracowników firmy $X$ osiąganego na drodze szkoleń i kursów. $W$ badaniach wykorzystano technikę wywiadu. 


\section{PRZYKŁAD 5}

Zadanie poznawcze rozwinięte w pracy dyplomowej:

- odpowiedź badanego na pytanie: czy któreś z zadań poznawczych nowych i cennych, odszukanych za pośrednictwem T3/ZOOM znalazło swoje rozwinięcie $\mathrm{w}$ pracy licencjackiej - tak;

- opinia promotora: wskazane zadanie poznawcze znajduje realizację w pracy dyplomowej pośrednio - tak, ale częściowo;

- ocena jurorów: zadanie poznawcze jest detalem pracy licencjackiej II stopień (wykorzystania zadania poznawczego w pracy licencjackiej.

Hasło wyjściowe: bezrobocie

\begin{tabular}{|c|c|c|c|}
\hline & $\begin{array}{l}\text { to, co widać } \\
\text { na pierwszy rzut oka }\end{array}$ & $\begin{array}{l}\text { to, co mniej widocz- } \\
\text { ne }\end{array}$ & $\begin{array}{l}\text { to, czego nie wi- } \\
\text { dać, } \\
\text { a na pewno jest }\end{array}$ \\
\hline $\begin{array}{l}\text { "szkło } \\
\text { powiększające" }\end{array}$ & $\begin{array}{l}\text { brak pracy zgodnej } \\
\text { z kwalifikacjami } \\
\text { zawodowymi }\end{array}$ & $\begin{array}{l}\text { brak pracy zgodnej } \\
\text { z potrzebami we- } \\
\text { wnętrznymi, aspira- } \\
\text { cjami }\end{array}$ & $\begin{array}{l}\text { decyzja o porzu- } \\
\text { ceniu (lub nie } \\
\text { porzucaniu) } \\
\text { miejsca pracy }\end{array}$ \\
\hline \multirow{3}{*}{$\begin{array}{l}\text { "obiektyw } \\
\text { szerokokątny" }\end{array}$} & \multirow{3}{*}{ bezrobocie a wakaty } & $\begin{array}{l}\text { potrzeba przygoto- } \\
\text { wania wszechstron- } \\
\text { nego zawodowego }\end{array}$ & \multirow{3}{*}{$\begin{array}{l}\text { płynność rynku } \\
\text { pracy }\end{array}$} \\
\hline & & $\begin{array}{l}\text { konieczność zmiany } \\
\text { zawodów }\end{array}$ & \\
\hline & & $\begin{array}{l}\text { konieczność zmiany } \\
\text { pracy }\end{array}$ & \\
\hline
\end{tabular}

Agnieszka K.

Temat pracy: Rezygnacja z pracy

Fragment spisu treści:

\section{Praca i jej środowisko}

I.1. Praca jako wyznacznik statusu wartości

I.2. Aktywność zawodowa

I.3. Orientacja i wybór zawodu

I.4. Zmiana środowiska pracy i aktywności zawodowej

I.4.1. Decyzja o porzuceniu pracy 


\section{I.4.2. Bezrobocie}

I.4.3. Planowanie i podjęcie pracy

Podsumowanie

Badania własne: polegały na zweryfikowaniu czynników, z powodu których ludzie $\mathrm{w}$ wieku produkcyjnym porzucają miejsce pracy. Badania przeprowadzono wśród pracowników firmy $X$, będących $w$ wieku produkcyjnym (20-40 lat), którzy w swym doświadczeniu osobistym mieli decyzję o rezygnacji z pracy.

\section{Podsumowanie}

Eksperyment dotyczył T3/ZOOM - techniki dostrzegania zadań poznawczych. Zgromadzony materiał empiryczny pozwolił wskazać konkretne zależności między T3/ZOOM, jej użyciem do poszukiwania zadań poznawczych a następstwami wynikającymi z korzystania z techniki.

T3/ZOOM dyscyplinuje poznawczo, co wyraża się w tym, że odkrywane są podmiotowo nowe i cenne zadania poznawcze.

T3/ZOOM przynosi wyraźnie określone skutki. Następstwem doszukania się nowych i cennych dla jednostki zadań poznawczych jest rozwinięcie zadania w pracy licencjackiej.

Część odszukanych przez studentów zadań poznawczych, uznanych przez nich za nowe i cenne, nie została jednak podjęta $w$ pracach dyplomowych. Można sądzić, iż powodem tego stanu rzeczy może być:

- niedobór lub nieodpowiedniość argumentacji na rzecz przekonania promotora o cenności tematu;

- niepewność w prowadzeniu negocjacji na rzecz uczynienia zadania poznawczego tematem pracy licencjackiej;

- trwoga przed autorytetem promotora;

- uznanie przez promotora zadania poznawczego za mało ważne.

Znaczną trudność $\mathrm{w}$ przeforsowaniu przez studenta zadania poznawczego, mającego być jego tematem pracy dyplomowej, jest gotowa lista tematów prac licencjackich przedstawiona przez promotora studentom. Przyjęło się bowiem, iż na uczelniach wyższych powszechnie stosowany jest „kanon” stanowienia prac dyplomowych (lista tematów prac dyplomowych przedstawiana przez promotora studentom). Nadto, na uczelniach wyższych brakuje tradycji stanowienia tematów i zagadnień prac dyplomowych na podstawie zadań poznawczych odszukanych za pośrednictwem technik twórczego dostrzegania problemów i zadań poznawczych. 
Kanon stanowienia tematów prac dyplomowych nie jest oceniany przez autorkę negatywnie - stanowi on bowiem: po pierwsze - podstawę dla studentów, dla których odszukanie cennych zadań poznawczych, będących nicią przewodnią pracy dyplomowej, jest trudnym zabiegiem, po drugie punkt odniesienia, jakie zadania (tematy prac dyplomowych) są znaczące poznawczo.

Niemniej należy podkreślić, iż łatwiej przychodzi kadrze dydaktycznej zdać się na swobodę myślenia i zaufać twórczości studentów, kiedy przedsięwzięcie ma charakter cząstkowy. Praca dyplomowa stanowi zaś podstawę weryfikacji wiedzy, jest uwieńczeniem procesu kształcenia na uczelni. Kadrze dydaktycznej trudniej w tym przypadku przełamać nawyki.

T3/ZOOM nakłania do aktywności indywidualnej. Każdy z badanych sam pokonywał, krok po kroku, procedurę techniki. Indywidualnej aktywności twórczej sprzyjały pewne warunki "zewnętrzne” i „wewnętrzne”. Zapewniono atmosferę wolności, porozumienia i akceptacji środowiska. Aktywność twórcza może się w pełni urzeczywistniać w otwartym i swobodnym klimacie porozumienia $z$ drugim człowiekiem.

Niewątpliwie "wewnętrznymi" warunkami zaistnienia aktywności twórczej są uruchomione pewne funkcje psychiczne i operacje intelektualne.

Technika T3/ZOOM jest techniką dostrzegania problemów i zadań poznawczych. Szukając problemów i zadań poznawczych za pośrednictwem T3/ZOOM uruchamiane jest myślenie twórcze. Myślimy dywergencyjnie rozbieżnie. Wielość odpowiedzi (wielość dostrzeżonych problemów i zadań) spełnia warunki techniki heurystycznej. Elastyczne myślenie ułatwia rozważenie licznych możliwości. Umożliwia dotarcie do istoty rzeczy, rozpoznanie tego co ważne dla danej sytuacji i jednocześnie widzenie tejże sytuacji w szerszym kontekście, jakby razem. Sytuacja penetrowana jest na drodze analizy, uruchomione zostają procesy wyobrażeniowe, uwaga skupiona jest na temacie. Ciekawość spojrzenia na sytuację, podniecenie $\mathrm{w}$ dociekaniu problemu, a być może i odczucie trudności towarzyszące doszukiwaniu się problemu czy zadania budują zaangażowanie emocjonalne. Wyraźna potrzeba poznania i wyjaśnienia tego co nieznane, niepewność odkrycia, a i wyrozumiałość wobec napięć i niejasności tworzą wewnętrzną „atmosferę" osoby stosującej technikę. Motywacja ukierunkowana na cel - znalezienie problemu lub zadania poznawczego - steruje tymi emocjami. Motywują raczej bodźce wewnętrzne niż zewnętrzne. Reprezentowana przez stosującego technikę T3/ZOOM postawa twórcza uruchamia w nim wrażliwość na problemy, czyni go otwartym na odkrycia i gotowym na wyzwania, które umykają uwadze innych. 
Można przyjąć, iż procedura techniki T3/ZOOM motywuje do wysiłku pracy twórczej, uruchamia wrażliwość na problemy, ciekawość poznawczą, motywuje immanentnie, rozbudza emocje, zwłaszcza te związane z odkrywaniem czegoś nowego i cennego - odczucie trudności.

Cennym następstwem wprowadzenia T3/ZOOM w proces edukacyjny jest zainteresowanie techniką samych promotorów. Zauważyli oni bowiem możliwość wykorzystania T3/ZOOM na własnych zajęciach seminaryjnych do szukania zadań, mogących stanowić zaczyn prac licencjackich i magisterskich. Ocena merytoryczna techniki, wskazana przez wykładowców, okazała się pozytywna - podstawą jej było spostrzeżenie, że:

- w pewnym stopniu może gwarantować zaangażowanie studenta $\mathrm{w}$ pisanie pracy dyplomowej;

- może przyczynić się do podniesienia poziomu merytorycznego pracy dyplomowej;

- przynosi satysfakcję studentom z napisania pracy na wyszukany przez nich temat;

- może wspomóc studenta w nakreśleniu obszaru, tematyki przyszłej pracy dyplomowej, gdy ten nie ma określonych preferencji tematycznych.

Istotną uwagą okazała się i ta, że chętniej promotorzy zaproponowaliby użycie techniki do poszukiwania zadań poznawczych do określonej, konkretnie sprecyzowanej problematyki, aniżeli pozostawiliby „otwarte pole” do poszukiwania zadań studentom.

Odnotowano także zainteresowanie T3/ZOOM jako techniką mogącą wspomóc zajęcia teoretyczne, prowadzone $\mathrm{w}$ formie wykładów problemowych. Po wprowadzeniu tematu wykładu studenci doszukują się zadań poznawczych i to one stają się zaczynem przekazania wiedzy i poprowadzenia dyskusji. W tym przypadku T3/ZOOM wzbogaca i urozmaica wykład problemowy, zwiększa poziom zainteresowania studentów, studenci czynnie i aktywnie uczestniczą w zajęciach.

Zainteresowaniem otoczyli T3/ZOOM wykładowcy prowadzący zajęcia laboratoryjne i ćwiczenia. Na tego typu zajęciach częstokroć wykorzystuje się projekt jako formę zaliczenia przedmiotu. Prowadzącemu zaproponowano przeprowadzenie zajęć zgodnie $\mathrm{z}$ tokiem przyjętym $\mathrm{w}$ eksperymencie wstępnym $^{28}$ : indywidualne przez studenta poszukiwanie zadania poznawczego, typowanie przez niego najbardziej interesującego zadania $\mathrm{z}$ odszukanych, negocjowanie $\mathrm{w}$ grupie zadania, które będzie realizowane przez zespół.

${ }^{28}$ M. Olczak, Jakość dostrzegania problemów i zadań poznawczych, s. 99-150. 
Warto $\mathrm{w}$ tym miejscu poczynić spostrzeżenie, że oto nie na każdych zajęciach można posiłkować się T3/ZOOM. Wykorzystanie techniki nie będzie nagminne, permanentne, ciągłe. Jednakże, T3/ZOOM wzbudza zainteresowanie wśród wykładowców, wykorzystywana jest na wybranych zajęciach do wybranych tematów. Jak podkreślają prowadzący zajęcia, klarowna, uporządkowana procedura techniki wyjątkowo sprzyja generowaniu inżynierskich zadań poznawczych.

Powyższe następstwa wskazano na podstawie opinii wykładowców, pozyskanych w toku swobodnie prowadzonych wywiadów.

\section{BIBLIOGRAFIA}

Altszuller G.S., Algorytm wynalazku, Książka i Wiedza, Warszawa 1972.

Arlin P.K., Wisdom: the art. Of problem finding, [w:] Wisdom: Its nature, origins and development, red. R.J. Sternberg, Cambridge University Press, New York 1990.

Bransford J.D., Stein B.S., The Ideal Problem Solver, W.H. Freeman, New York 1993.

Dewey J., Jak myślimy? PWN, Warszawa 1988.

Florida R., The Rise of the Creative Class and How It's Transforming Work. Leisure, Community and Everyday Life, Basic Books, New York 2002.

Getzels J.W., Csikszenmihalyi M., The creative vision: A longitudinal study of problem finding in art, Wiley, New York 1976.

Isaksen S.G., Dorval K.B., Treffinger D.J., Creative approaches to problem solving, Kendall/Hunt, Dubuque 1994.

Jay E.S., Perkins D.N., Problem finding: the Search for Mechanism, [w:] The Creativity Research Handbook, red. M.A. Runco, Hampton Press, Cresskill, New Jersey 1997.

Kozielecki J., Zagadnienia psychologii myślenia, PWN, Warszawa 1968.

Kozielecki J., Twórczość i rozwiązywanie problemów, [w:] Psychologia i poznanie, red. M. Materska, T. Tyszka, PWN, Warszawa 1992.

Newell A., Simon H.A., Human Problem Solving, Englewood Cliffs, Prentice-Hall, New York 1972.

Nęcka E., Proces twórczy i jego ograniczenia, Wydawnictwo Uniwersytetu Jagiellońskiego, Kraków 1987.

Nęcka E., TRoP. Twórcze rozwiązywanie problemów, Oficyna Wydawnicza Impuls, Kraków 1994.

Nęcka E., Proces twórczy i jego ograniczenia, Oficyna Wydawnicza Impuls, Kraków 1999.

Nęcka E., Twórczość, [w:] Psychologia, red. J. Strelau, Gdańskie Wydawnictwo Psychologiczne, Gdańsk 2000.

Olczak M., Trening twórczości - wspótczesna i efektywna forma wychowania przez sztukę, Oficyna Wydawnicza Impuls, Kraków 2009.

Olczak M., Jakość dostrzegania problemów i zadań poznawczych - istotny czynnik wychowania do twórczości. T3/ZOOM technika wspomagania rozwoju myślenia twórczego uczących się, Wydawnictwo Politechniki Łódzkiej, Łódź 2013.

Oldham G.R., Cummings A., Employee Creativity: Personal and Contextual Factors at Work, The Academy of Management Journal, 1996, 39, 3. 
Polya G., Jak to rozwiazzać?, PWN, Warszawa 1993.

Proctor T., Twórcze zarządzanie, Gebethner \& Ska, Warszawa 1998.

Runco M.A., Creativity as optimal human functioning, [w:] Promoting creativity across the life span, red. M. Bloom, T.M. Gullotta, CWLA Press, Washington 2001.

Stasiakiewicz M., Interakcyjne podejście do badania zachowań twórczych, [w:] Psychologiczne i psychometryczne problemy diagnostyki psychologicznej, red. J. Brzeziński, Wydawnictwo Naukowe UAM, Poznań 1993.

Szmidt K.J., Szkoła przeciw myśleniu pytajnemu uczniów: próba określenia problemu, sugestie rozwiązania, Teraźniejszość - Człowiek - Edukacja, 2003, 2.

Wertheimer M., Productive Thinking, Harper \& Row, New York 1945. 